\title{
Why I Left Psychology (Almost): A Fictional Story That Might Be True
}

\author{
David N. Elkins, Ph.D.
}

Editor's Note: David Elkins writes about ethics, using the example of dual relationships, from a long and rich background in clinical and academic psychology. He raises important questions about what it means to be ethical, and whether that meaning has been reduced to legalistic discussions of rules of conduct. For those who agree that there must be a more holistic approach, Cedar Barstow's article "Ethics: The Right Use of Power and Influence" in Issue 10 of the Hakomi Forum may be consulted. Dr. Elkins article was first published in The Humanistic Psychologist Vol. 34 No. 2 (2006): 99-110, and is reprinted here with permission.

David N. Elkins, Ph.D., is a clinical psychologist and a professor emeritus of psychology in the Graduate School of Education and Psychology at Pepperdine University. He has been president of Division 32 of the American Psychological Association, and a board member of the Association for Humanistic Psychology. In 1998, he published Beyond Religion: A Personal Program for Building a Spiritual Life Outside the Walls of Traditional Religion (Quest Books). Correspondence concerning this article should be addressed to David N. Elkins, Professor Emeritus, Graduate School of Education and Psychology, Pepperdine University, 6100 Center Drive, Los Angeles, CA 90045. Electronic mail may be sent via Internet to davidnelkins@hotmail.com

\begin{abstract}
This fictional, humorous article pokes fun at one of our profession's sacred cows and raises fundamental questions about our increasingly legalistic approach to ethics. The intent is not to make fun of genuine professional ethics but to point to a deeper, more sophisticated understanding of this important topic. The article is entirely fictional and the characters and settings are not real. However, if you think you recognize some of the characters in the story, perhaps even yourself, you could be right because the article is indeed "a fictional story that might be true."
\end{abstract}

\section{Introduction}

This introduction provides a scholarly frame for the fictional story that follows.

The English word ethics comes from roots that have to do with one's character, yet in psychology we increasingly use the term as a synonym for "rules of conduct" in the profession. Far too often those who teach "law and ethics" courses in graduate psychology programs and in continuing education classes focus on the many rules of the ethics code and spend little time discussing ethics per se. I fear we are training psychologists to be legalists instead of ethical professionals who know how to apply wisdom, compassion, and justice to the complex situations they confront as psychologists.

Years ago Kohlberg (1976) and Gilligan (1982) made us aware that there are different levels of moral development and functioning. Kohlberg posited a hierarchy of moral development that viewed legalistic rule-keeping as a sign of lower-level moral functioning and following high-level moral principles as the ideal. Gilligan pointed out limitations of Kohlberg's research and model and emphasized that a true "ethic of care" is not simply about following an abstract moral principle - even a worthy one but more about compassionately considering all those who will be affected by a particular action or decision. Kohlberg and Gilligan did agree, however, that there are degrees or levels of moral functioning and that legalistic adherence to rules represents a lower level of such functioning. In my fictional story readers will hear the echoes of Kohlberg and Gilligan.

In regard to the ethics of dual relationships, an issue addressed in my fictional story, Lazarus and Zur (2002) raised concerns about our profession's negative attitude toward all dual relationships and argued that certain carefully considered multiple relationships with clients can be not only ethical but highly beneficial. Their thoughtful, scholarly approach to this complex issue is a breath of fresh air in a profession where legalistic attitudes seem to be gaining ground and where it is sometimes difficult to determine how much of our ethical thinking is driven by genuine concern for clients and how much is driven simply by fear of lawsuits.

To avoid giving the wrong message, however, I would like to make it clear that I am not advocating that psychologists and clients (or professors and students) should be free to engage in any kind of dual relationship they wish. Indeed, certain dual relationships can be problematic, damaging, even disastrous. For example, I believe that sexual involvements with current clients or students should always 


\section{David N. Elkins}

be avoided. Having made that clear, however, I do agree with Lazarus and Zur that our profession has swung too far in the other direction, having become paranoid about all dual relationships and having failed to see the benefits of carefully considered multiple involvements, along with the very real damage that too much "professional distance" can do. I hope my fictional story will shed light on these issues.

Although I said my story is "entirely fictional," one small part is true. I actually was a conservative minister and left the church more than 30 years ago. My theological training involved a strong dose of ethics and one of the first lessons I learned as a young ministerial student was that ethics and rules are not the same. Genuine ethics has to do with the development of a just and compassionate human being. Rules, on the other hand, are the province of legalists who tend to become more concerned about rule-keeping than about what it means to be a truly good human being.

Regarding my personal views on the opinions expressed in the fictional story, I agree with all those who challenged the young professor in this sense: they were all at least intuitively aware that genuine ethics involves more than simply applying a black and white rule from an ethics code. I especially identify with the grandmotherly woman crocheting the afghan who took it upon herself to point out the difference between legalism and genuine ethics. She expressed my point of view beautifully - far better than I could have done myself.

Finally, just for the record: I am now retired and in my 30 years as a clinical psychologist and professor, I was never accused of an ethical violation nor was I ever the object of a lawsuit. The only way I can account for this is that I had very forgiving clients and students.

I hope you enjoy the following story and find that its humorous, fictional nature does not dim its illumination of a very serious topic.

\section{A Story: Why I Left (Almost). . .}

Awhile back I had reached the end of my rope with psychology. I was angry as hell and I wasn't going to take it any more. I hated HMOs, clerks with B.S. degrees telling me how and when I could treat my clients, APA formulating treatment guidelines to tell me how to practice, short-term therapies being taught to our graduate students so they can get jobs in the insane marketplace, psychologists seeking prescription privileges as though we don't have enough pillpushers in this country as it is, and colleagues all around me using models of therapy that would work better with robots and pigeons than with human beings. I'll admit it: I was one cynical S.O.B. I had talked it over with my wife and was making plans to refer my clients. As soon as the task was accomplished properly, I planned to turn in my license and do something more honorable such as selling used cars or working as a telemarketer.

But you don't know me from Adam, so let me back up and tell you a little about myself. I became a psychologist in 1973. For thirty years I've listened to clients' hopes and dreams. I've witnessed their courage in the face of tragedy and loss. I've watched middle-aged men who had lost their way find their souls again. I've seen abused women rise up and become strong. I've seen little boys and girls, depressed by burdens no child should have to bear, find joy again. I've seen marginalized people find their voice and become forces for change. I wouldn't trade these experiences for anything in the world. Nevertheless, I was going to turn in my license and leave the profession.

It wouldn't have been the first time I had bailed out of a profession. I grew up in the Bible belt and was originally trained as a fundamentalist minister back in the 1960s. After five years of giving it my best, I knew I wasn't cut out for the job. No matter how hard I tried, I couldn't follow all the rules and I felt like a hypocrite. I'd preach against lust, but find myself staring at the shapely bodies of female parishioners in the church parking lot as soon as church was over. I'd tell my parishioners to read the Bible every day, but I didn't do it myself. The truth is, I found the Bible pretty dull, especially those Old Testament passages about who begat whom and those stories about how God commanded his people to wipe out whole towns including the women and children. I found that hard to swallow. Also, I sometimes found it hard to pray for the sick, especially those who were obviously dying. I remember going to the hospital to visit a man in his thirties who was eaten up with cancer. In six months, he had gone from 175 pounds to 85 . He had a wife and two young kids who loved him more than anything else in the world. When I arrived, his wife took me aside and asked if I would beseech God for her husband's life. She used the word beseech because she thought it meant to beg God with everything in you. I knew her husband was going to die and there wasn't anything I could do about it, but when I saw the desperation in her eyes, I walked over to the bed, took the man's bony hand, and I beseeched God - as best I could -- to let this young husband and father live. He died two days later.

I think that's when I decided to leave the ministry. I wasn't good enough and didn't believe enough to be a man of God. I couldn't follow all the rules and I didn't have enough faith to save anyone. My family and I lived in Michigan at the time so I resigned from the ministry and took a job on the Fisher Body assembly line. My wife was with me all the way, but when my parents and the rest of my clan heard that I had left the ministry, they thought I was going crazy. I thought I was becoming sane.

It took me about a week to know I didn't want to build cars the rest of my life. I still wanted to help people. A friend 


\section{David N. Elkins}

asked me if I had ever considered becoming a psychologist. "Not really," I said. But after thinking about it for a couple of days, I thought it might work. Psychology was a secular profession and maybe it didn't have a bunch of rules and maybe you could serve others even if you weren't perfect. With a renewed sense of hope, I applied to a doctoral psychology program on the East Coast. To my surprise, they accepted me, and I began classes in the fall of 1969.

Almost immediately, I felt at home. I knew I had found my place in the world. Humanistic psychology was at its peak and almost every class I took, regardless of its title, turned into an encounter group where students and professors talked heart-to-heart. We didn't know about the horrible dangers of dual relationships in those days. We went to our professors' homes, drank beer with them at the local pizza place, and discussed everything from the sexual revolution to the heavy social issues of that time. My doctoral class of fifteen students was made up of whites, blacks, Jews, Latinos, Asians, and, of course, one former fundamentalist minister. We argued, got angry, cried, supported each other, and somehow found a way to stick together. One of our professors owned a cabin in upstate New York and once during spring break we all piled into cars and spent the week with him and his wife at their place in the mountains. I could not have received a better education.

One of my classmates, a bright Latino woman whom we all adored, was working at the university clinic. She fell in love with one of her male clients and he fell in love right back at her. She discussed this openly in our practicum class and tried, unsuccessfully, to work through her feelings. Ultimately, she decided her feelings were real and not simply countertransference. Our practicum professor, an elderly gentleman who was both wise and kind, told her she must bring the therapy to an end, make sure the young man was properly referred to another therapist, and then he saw no reason they couldn't date. The young woman handled the situation beautifully. A year later she and her former client were married. Today, they have three grown children and four grandchildren. I attended their thirtieth wedding anniversary last August and they're still in love with each other.

During the second year of my doctoral program, I had a group therapy class with a wonderful professor. When the course came to an end, I asked her if she would take me as a client. She said that if I didn't plan to take any more classes with her, she would be glad to see me in therapy. Since I was a graduate psychology student, she asked if I would like to serve as a co-therapist in one of the therapy groups she ran at her clinic. I jumped at the chance. I had my personal therapy with her on Tuesday mornings and then I'd help her run the therapy group on Tuesday nights. My group work often brought up issues for me that I would discuss in my personal therapy. She was my support system through the rest of my doctoral program and wrote me a glowing letter of recommendation that helped me land a top-notch internship. Through my multiple relationships with this brilliant and caring woman, I gained confidence and maturity as both a person and a professional.

I completed my internship after a year and graduated in 1972 with my Ph.D. in clinical psychology. A year later I passed the state licensing exam and in 1973 five of my classmates and I, along with one of our favorite professors who was retiring from the university, started a clinic. Our beloved professor died in 1994, but the rest of us still work together at the same clinic. We have served more than 20,000 clients over the past thirty years.

Fortunately, none of us has ever been sued and only one of us - a man whom I'll call John -- has ever been accused of an ethical violation. A little over a year ago, John was working with a female client who began showing up at our clinic at odd times and demanding to be seen. After rearranging his schedule a couple of times to accommodate her, he finally told her that unless it was a true emergency, she would have to stick with her regular appointments and that he would not see her any more on a "walk-in" basis. A few days later the client sent a letter to the state psychology board saying that John had "abandoned" her and that if they didn't revoke his license, she would sue both John and the committee. The board took nearly a year to investigate the matter. The five-member committee interrogated John on two different occasions for more than two hours each time. John had to get colleagues to write letters on his behalf and he consulted his attorney numerous times while the investigation was going on. Finally, after a year the psychology board decided the allegation was groundless and dismissed the charge. Of course, John's life had been disrupted and he had been pushed to the brink of depression worrying and trying to defend himself against a ridiculous charge. John is one of the kindest, most ethical people I know. It was hard to see him go through that.

For me, John's ordeal was the last straw. As I said earlier, I was already disillusioned with my profession so it was easy to decide to quit. However, because the expiration date of my psychology license was coming up soon, I knew I'd have to renew it in order to have time to end with my clients. That meant I'd have to finish my continuing education units required to renew my license. Ironically, the one CE class I still needed was "Law and Ethics."

The "Law and Ethics" class, which was offered as a one-day workshop in a nearby city, was taught by a young professor who had gotten his doctorate a couple of years before at a well-known school on the West Coast. As he began the class, he told us quite proudly that he had always wanted to be a lawyer, but had decided at the last minute to become a psychologist instead. With that introduction, he launched into what would turn out to be a seven-hour lecture, with a lunch break in the middle, focused mainly on the ethics code of the American Psychological Association. 


\section{David N. Elkins}

The young professor had a way with words and with his lawyer-like mind he managed to ferret out nuances from the ethics code that I had never even considered. He peppered his lecture with case illustrations to show how easily -- and sometimes without even knowing it -- one could become an unethical psychologist. He handled questions from the audience with ease, giving thorough and crystal-clear answers.

At one point he was talking about the requirement in the ethics code that psychology training programs must tell students before entering the program if they will be expected to discuss personal information as part of their training. An old professor sitting next to me raised his hand. "Are you telling me," he asked, "that I could be brought up on ethical charges if I ask students in my group psychotherapy class to share something personal about themselves -- even if I make it clear that they can share at whatever level they wish?" The young professor smiled benevolently across the forty years that separated him from the old gentleman. "Let's put it this way," he said, with just a touch of condescension. "If your university has not officially informed students when they applied to the program that they could be asked to share personal information in some classes, then you would be ethically at risk if you were to ask your students to tell anything of a personal nature." The old gentleman shook his head in disbelief and went back to doodling on his notepad but I heard him say under his breath, "What the hell do they think psychology is about anyway?"

The professor continued his exegesis of the ethics code. By the time we broke for lunch, I had counted thirteen violations I was quite sure I had committed and thirty-three others that were real possibilities. I was scared and having fundamentalist flashbacks. The professor reminded me of ministers I knew as a boy who seemed to enjoy naming all the sins one could commit that would send you to hell. I flashed back to my ministerial training and to the famous sermon by Jonathan Edwards titled "Sinners in the Hands of an Angry God." Members of his congregation had actually fainted when Edwards described in graphic language how sinners dangle by nothing but a thread over the fires of hell. After listening to the young professor, I knew that I was dangling by a thread over the fires of psychology hell and my only hope was that my clients would be nice enough not to turn me in. What scared me most -- which also reminded me of my fundamentalist upbringing -- was that ignorance and good intentions made no difference. The young professor had made it clear: If we violated the ethics code, we would be cast into hell and nobody -- certainly not the American Psychological Association -- would come to our rescue.

I went to a fast food restaurant for lunch and had a sourdough burger and a large diet coke. Fast food always calms my nerves so by the time I returned for the afternoon session, I was feeling better and thought maybe I had simply overreacted. Little did I know that the worst was yet to come. The afternoon session focused on multiple relationships and the young professor described in great detail all the sins one could commit related to such relationships. For example, he told us in no uncertain terms that we were putting ourselves at grievous ethical risk if we became friends with a client when therapy ended. He said that while the ethics code did not directly address this issue, almost all problems between therapists and former clients had begun with such "boundary violations."

A woman at the back of the audience who was crocheting a purple afghan and wearing beads she had apparently salvaged from the sixties pointed out that this was strange since the ethics code allowed therapists, if certain stringent criteria were met, to date a former client two years after therapy ended. Holding the afghan up to inspect her work, she asked the young professor nonchalantly, "Does that mean I can have sex with a client after two years so long as we don't become friends?" The audience cracked up. We thought she was pretty funny. The young professor didn't. "Are you making fun of the ethics code?" he asked, with a sternness that reminded me of Jerry Falwell. "Of course not," said the woman as she began crocheting again. "I would never poke fun at a sacred cow."

The young professor didn't quite know what to say. After all, the woman was old enough to be his grandmother and judging by the laughter, the class seemed to be on her side. So he cleared his throat and took up where he had left off, forging ahead to describe more perils of multiple relationships.

"Suppose your client owns a car dealership in town," he said, "and you are in the market for a new car. Should you buy your car from your client or should you go somewhere else?"

An attractive young woman sitting on the front row asked quickly, "Current client or past client?"

The professor smiled. I got the feeling he liked the young woman. She had wild blonde hair, wore tight blue jeans, and had a body that would stop a train - not that I had noticed, of course.

"Let's say for sake of argument that he's a current client," replied the professor.

"Then no way," said the young woman. "If you bought a car from him, it could mess up the transference big time."

"Ding!" said the professor. "You get an 'A' in my class."

The young woman smiled. She had nice lips and perfect white teeth. "Why thank you, Professor," she said in a coy voice that somehow reminded me of Britney Spears. 


\section{David N. Elkins}

I couldn't help but wonder if we were witnessing a dual relationship in-the-making. To be honest, I was feeling a little old and jealous. At that moment I would have been glad to see the handsome young professor dangle over hell and even drop - as long as he left Britney behind.

"Now, let's make it more difficult," said the professor. For a minute, I thought we were about to go deep. I was wrong. "Suppose the car dealer's therapy had ended a year ago. Would it be okay for you to buy a car from him?"

This was obviously too complex a question for Britney. Besides her score was perfect so far and I had the feeling she didn't want to mess it up by saying something stupid.

A man sitting across the aisle from me - I'd say he was in his early forties -- raised his hand. "Generally speaking, I think it would be okay," he said. "I worked in a small town in South Carolina for ten years and actually faced this problem. One of my clients was the local car dealer - the only dealer for miles around. He came to see me for about a year. I bought one car from him when he was my client and a couple of others through the years after he ended therapy. I can't see that it hurt anything. In fact, I think he would have been upset with me if I hadn't bought from him."

The young professor nodded. He had decided to try a more understanding approach. "Well, in the old days," he said, "such loose ethics were quite common, especially in small towns. But if you lived there today, what would be the ethical thing to do?"

The man looked a little put-out with the professor. I figured the term "old days" or maybe "loose ethics" is what had riled him.

"Well, I guess I'd just have to forget ethics and do the right thing," he said with a rising voice and a heavy Southern accent I hadn't noticed before. "I'd buy my cars from him just like I always did and I'd also have him over for supper if I wanted to!"

This was a pretty direct challenge to the professor's authority and several of us sat up in our seats to see what would happen. The professor was red-faced and the veins on his perfectly tanned neck were standing out. For a minute I thought he was going to jump over desks and tear the man's heart out. Instead, he pointed his well-manicured finger at the man -- and at all us dangling sinners, I thought. "Listen to me," he said. "Some of the best minds in our profession wrote these ethical standards. They are designed to guide us, protect us, and keep us from being sued. If you want to ignore them or make fun of them, then go ahead, but remember this: you will end up before an ethics committee, very possibly lose your license, and be personally and professionally humiliated and disgraced." By the time he finished, he was almost shouting. I was having a panic attack and had slouched down in my seat waiting for an angel of God to swoop down and cut the threads of those of us who were dangling over hell because of multiple relationships with car dealers.

The woman with the afghan didn't seem particularly perturbed. "I always thought ethics was about love, compassion, and making sure we treated our clients with dignity and respect," she said, her quiet voice in stark contrast to the professor's loud ranting that still hung in the room. "Unfortunately, classes like this, along with those we get in graduate school, always focus on rules -- and rules don't have much to do with ethics, really."

Everybody became quiet. The woman continued. "I wonder how many of those who wrote the ethics code have formal training in ethics. And what about those who teach ethics in our graduate programs and in continuing education classes like this one? If I were to guess, I'd say very few have training in ethical thought. Ethics is a huge and complex field. I have two doctorates, one in philosophy with a specialization in ethics and one in clinical psychology. The program in ethics was much more difficult than the psychology program."

She looked at the professor and gave him a grandmotherly smile. "You seem like a nice young man," she said, not a trace of condescension in her voice. "But let me ask you: do you have any formal training in ethics?"

The professor stammered. "Well, I . . I . . I have spent my entire professional life studying law and ethics in psychology," he said.

"I'm sure you have," said the woman," and you are very bright and articulate. But based on what I've heard here today, I'd say you're a legalist -- one who knows all the rules but little about ethics.”

At this point I was getting intrigued and had even stopped watching for swooping angels.

The woman continued, "Legalism is an old problem when it comes to ethics. People start out with good intentions. They know that compassion and justice are important, so they attempt to capture these qualities in a written code. It never works because people begin to focus on the rules and forget about the values that gave rise to the rules in the first place. Genuine ethics can never be captured in a list of rules, no matter how detailed. In fact, rules tend to kill compassion and justice. As one of my philosophy professors used to say, "When the spirit of compassion dies, its remains are embalmed in the form of an ethical code."

She paused for a moment to let that sink in, and then continued. "And why do we have all these detailed rules about multiple relationships? That kind of tediousness is rather new in psychology and I suspect it came about primarily due to lawsuits, not good ethical thinking. 


\section{David N. Elkins}

Certainly, we must never exploit or damage our clients through multiple relationships, or in any other way. The same is true of professor-student relationships. I'm a professor, so let me speak to that. The legalists in our profession seem so concerned about personal sharing and multiple levels of connection between professors and students. Of course, we all know professors who have exploited students, just as we know unscrupulous therapists who have taken advantage of clients. But just because we have unethical professionals among us who use personal connections and open sharing to exploit students and clients, does this mean that personal connections and open sharing are therefore inherently suspect? What kind of twisted thinking leads us to such ridiculous conclusions?"

She looked up from her crocheting to see if anyone cared to answer her rhetorical question. When no one said anything, she continued. "And then there's the ethical issue that no one ever seems to address: What damage is done when we are so concerned about multiple relationships that we never go to lunch with our students, never invite them to our homes, never interact with them anywhere except in the cold environs of classrooms and faculty offices? Or what does it do to the soul of a student who speaks of something personal in class and is then told by the professor, explicitly or implicitly, that such topics are not appropriate in the classroom. What message does this send to students about opening up their hearts, about becoming warmer and more compassionate human beings? What message does it give our students about how to treat their own students when they become professors?

As an ethicist, I find it strange that no one in psychology seems to be asking about the damage that emotionally unavailable professors do, not to mention emotionally unavailable therapists whose name is legion. When I was a graduate student, the professors who damaged me most were those who had such "good boundaries," as we say, that I always felt like an object on the other side of their walls. I find it puzzling that in other areas of society we condemn those who treat others as objects but in psychology we not only continue to treat others as objects but we invent jargon such as "good boundaries" and "blank screens" to justify our aloofness and unavailability. Here's what I believe:
Anything we do that diminishes our clients' or our students' humanity is unethical."

The woman stopped and the room was silent. Her last sentence seemed to hang in the air. Anything we do that diminishes our clients' or our students' humanity is unethical. We were in the presence of wisdom and we knew it. Some of us, reminded of more humane times in our profession, had tears in our eyes. Even Britney and the young professor were quiet. I wasn't sure either of them had actually gotten the point, but at least they knew when to be silent. Finally, someone noticed the time and said, "It's 5:00 o'clock. Time to go." We all got up and filed silently out of the room, picking up our CE certificates on our way out the door.

When I got home, my wife was in the yard tending the roses.

"How'd your class go?" she asked. "Was it as boring as you predicted?"

"No, it actually turned out to be pretty good," I said.

For some reason, I wanted to break through boundaries, so I walked over and gave her a hug. "Honey, I think I'll stay at the clinic after all," I said. "Would that be okay with you?"

"Of course," she said. "I was hoping you wouldn't quit. I know how much you love what you do."

I just smiled and didn't say anything. I went in the house and began making phone calls to some old colleagues and clients -- just to tell them how much they meant to me.

\section{$\underline{\text { References: }}$}

Gilligan, C. (1982). In a different voice. Cambridge: Harvard University Press.

Kohlberg, L. (1976). The meaning and measurement of moral development. Worcester, MA: Clark University Press.

Lazarus, A. A. \& Zur, O. (Eds.) (2002). Dual relationships and psychotherapy. New York: Springer. 